\title{
Maldi-tof mass spectrometry for the identification and detection of antimicrobial activity of lactic acid bacteria isolated from local cheeses
}

\author{
Eda Kılıç KANAK ${ }^{1}$, Suzan Öztürk YILMAZ ${ }^{1 \star}$
}

\begin{abstract}
In this study, 21 traditionally made cheeses were used. A total of 150 lactic acid bacteria (LAB) isolates were obtained from cheeses. 100 of them were identified at genus levels as Leunoconostoc (10), Lactobacillus (46) and Enterococcus (44) using biochemical tests. 71 strains were identified as Enterococcus durans (6), E. faecalis (18), E. faecium (24), E. italicus (2), Lb. brevis (1), Lb. paracasei (2), Lb. plantarum (1), Lactococcus lactis (3), Leuconostoc lactis (1), Leu. mesenteroides (11), and Streptococcus parauberis (2) at species levels using MALDI-TOF MS analysis. 10 of 100 isolates that showed antimicrobial activity were obtained from 21 samples of local cheeses. LAB strains were centrifuged to obtain supernatants in order to investigate two mechanisms. First, unprocessed supernatant was used to examine total antibacterial effect. Second, bacteriocins were obtained from LAB strains isolated using partial purification. The Kirby-Bauer Disk diffusion method was used to compare their antimicrobial activity against six pathogen. In conclusion, the bacteriocin produced from E. faecium shows higher antimicrobial activity than the others, and therefore, it can be used as a biological preservatives to extend shelf life.
\end{abstract}

Keywords: antimicrobial activity; bacteriocin; MALDI-TOF MS; lactic acid bacteria; local cheese.

Practical Application: Use of lactic acid bacteria (LAB) as additives in food products.

\section{Introduction}

When preparing food products, any hazards and risks that may affect human health must be considered. Consumers prefer natural and nutritious food products with no chemical additives. Use of lactic acid bacteria (LAB) is a natural and preferable preservation method.

Research shows that LAB, especially in milk and milk products, are widely available in nature and used as starter cultures for fermentation in dairy industries. In order to shorten the fermentation process and to reduce the risk of fermentation failure, it is necessary to consciously select and use a starting culture (Leroy \& De Vuyst, 2004). Despite the limited commercial availability of new starter cultures, LAB can replace chemical additives and help to provide attractive and diverse food products (Pidcock et al., 2002). LAB have recently gained growing interest due to their proteolytic activities and use as protective cultures (Tulini et al., 2016).

Macaluso et al. (2016) obtained 699 LAB strains isolated from traditional Sicilian cheese and raw milk. Listeria monocytogenes, Staphylococcus aureus, Escherichia coli, and Salmonella Enteritidis bacteria were used to investigate antimicrobial activity. A total of 223 strains were found to inhibit the growth of L. monocytogenes. It has been reported that bacteriocin-producing cultures in dairy products improve the quality and safety of those products in a more practical and cost-effective way. El-Ghaish et al. (2017) state that bacteriocins and/or bacteriocin producing LAB should be used as food preservatives to improve the safety of food products (i.e.; cheese and yoghurt). To determine these lactic acid bacteria, a lot of research has been done. Nacef et al. (2017) identified the culturable population of LAB from a French cheese Maroilles made either with raw or pasteurized milk using MALDI-TOF mass spectrometry. All strains unambiguously identified. MALDI-TOF MS identification allowed identification of three genera belonging to LAB including Lactobacillus, Enterococcus and Leuconostoc. Meghoufel et al. (2017) MALDI-TOF MS procedure used to identify 36 lactic acid bacteria isolated from Jben cheese. Kačániová et al. (2017) identified LAB from cow cottage cheese using the MALDI-TOF MS. Respectively, the results showed the domination of the Enterococcus and Lactobacillus genus presents in these cheeses. Although there are various kinds of traditional cheeses in Turkey, LAB that can be used as possible starter cultures isolated from these cheeses have not yet been adequately identified.

The aim of this syudy is to identify potential starter cultures and bacteriocins in order to improve the production quality of various regional cheeses in Turkey. For this purpose, LAB that are used in traditional cheese production were isolated from natural products and identified using biochemical tests and MALDI-TOF MS (Matrix-Assisted Laser Desorption/İonization) method to investigate their antimicrobial properties.

\section{Materials and methods}

\subsection{Materials}

A total of 21 non-commercial cheese samples were collected from eight villages in Turkey (The various locations are indicated with codes in Table 1). The codes indicated in 
Table 1. Provinces, codes and names of the cheeses used in the research.

\begin{tabular}{|c|c|c|c|c|c|}
\hline Province & Cheese name & Code & Province & Cheese name & Code \\
\hline \multirow[t]{6}{*}{ Sakarya } & Circassian cheese & A & Giresun & Bryndza & B \\
\hline & Urfa cheese & $\mathrm{E}$ & & Bryndza & $\mathrm{C}$ \\
\hline & Herby cheese & $\mathrm{F}$ & & Tecen cheese & G \\
\hline & Bryndza & $\mathrm{P}$ & & Bryndza & $\mathrm{H}$ \\
\hline & Lavaş cheese & $\mathrm{R}$ & & Bryndza & I \\
\hline & Farm cheese & M & & & \\
\hline Artvin & String cheese & $\mathrm{N}$ & & Cottage cheese & $\mathrm{D}$ \\
\hline Bolu & Gerede cheese & $\mathrm{J}$ & Karaman & Obruk cheese & $S$ \\
\hline \multirow[t]{2}{*}{ Erzurum } & String cheese & $\mathrm{K}$ & Tekirdağ & Cream cheese & $\mathrm{T}$ \\
\hline & Farm cheese & $\mathrm{L}$ & & Fat cheese & $\mathrm{U}$ \\
\hline Trabzon & Farm cheese & $\mathrm{O}$ & & Dokuz höyük cheese & $\mathrm{Y}$ \\
\hline
\end{tabular}

Table 1 were used to show which isolates where obtained and in which cheese. The cheeses were produced by the local people of the villages using traditional methods. Samples were stored at $4{ }^{\circ} \mathrm{C}$ in sterile sample containers and brought to the Food Microbiology Laboratory of the Department of Food Engineering of Sakarya University

\subsection{Lactic acid bacteria isolation from cheese samples}

For the isolation of lactic acid bacteria (LAD), cheese samples $(10 \mathrm{~g})$ were homogenized with $90 \mathrm{~mL}$ sterilized buffered peptone water. Afterwards, serial dilutions $\left(10^{-1}\right.$ to $\left.10^{-6}\right)$ were performed and $0.1 \mathrm{~mL}$ of each dilution was platted onto de Man, Rogosa and Sharp (MRS) (Merck, Germany) agar, M17 (Merck, Germany) agar and Kanamycin Esculin Azide Agar (KAA) (Merck, Germany) plates. The M17 and MRS plates were incubated at $30^{\circ} \mathrm{C}$ for $48 \mathrm{~h}$ and the KAA plates were incubated at $37^{\circ} \mathrm{C}$ for 24 to $48 \mathrm{~h}$. The plates were also incubated both in anaerobic and aerobic environments. Anaerocult A (Merck) was used to isolate bacteria developing in the anaerobic environment.

150 individual morphologically distinct isolates/colonies were randomly-picked from MRS agar, M17 agar and KAA plates. They were sub-cultured and purified three times in an MRS medium. For the selection of isolates, small, white or pale rectified and smooth-edged colonies were selected for enterococci. Cream-colored, smooth-edged columns were selected for lactobacilli while white, smooth-edged and bright colonies were selected for lactococci. Isolates inoculated into MRS Broth or M17 Broth were incubated for $48 \mathrm{~h}$. Stocks were prepared from $800 \mu \mathrm{l}$ of LAB cultured in MRS broth or M17 broth. $200 \mu \mathrm{l}$ of sterile liquid glycerol ( $800 \mu \mathrm{L}$ active isolate $+200 \mu \mathrm{L}$ glycerol) was mixed in a $1 \mathrm{~mL}$ Eppendorf tube and stored at $-80{ }^{\circ} \mathrm{C}$ (Harrigan \& McCance, 1990). Prior to each analysis, the isolates were activated in MRS, M17 and KAA.

\subsection{Microbiological and biochemical characterization of lactic acid bacteria isolates}

Morphological, physiological and biochemical characteristics were used to identify LAB. 150 pure bacterial isolates were tested for cell morphology, gram reaction and catalase production. Only 100 of them were Gram positive and catalase-negative. Growth tests were performed at different $\mathrm{NaCl}$ concentrations $(4,6.5 \%)$, temperatures $\left(10,15\right.$ and $\left.45{ }^{\circ} \mathrm{C}\right)$ and $\mathrm{pH}$ values $(9.2,9.6)$. Mobility characteristics and gas production were tested (Harrigan \& McCance, 1990; Halkman, 2005).

\subsection{Gram staining and catalase test and mobility test}

Gram staining and catalase test were performed in accordance with the methods described by Temiz (2000). Mobility test was performed in accordance with the method described by Halkman (2005).

\subsection{Development tests of isolates at different temperatures, salt concentrations and $\mathrm{pH}$}

Sterile $5 \mathrm{~mL} \mathrm{M17}$ and MRS Broth media with 1\% isolate were incubated at $10{ }^{\circ} \mathrm{C}, 15^{\circ} \mathrm{C}$ and $45^{\circ} \mathrm{C}$ for $48 \mathrm{~h}$. Turbidity was taken into account when evaluating the data. M17, MRS and KAA mediums containing $4 \%$ and $6.5 \% \mathrm{NaCl}$ were used to determine the salt tolerance of bacterial isolates. The isolates were inoculated on an agar medium and their growth was examined after incubation at $37^{\circ} \mathrm{C}$ for $48 \mathrm{~h}$.

3.0 mL M17 and MRS Broth media with pH 9.2 and 9.6 were inoculated with the isolates. $1 \%$ isolate was added to the MRS and M17 Broth media. They were incubated at $30^{\circ} \mathrm{C}$ for $7 \mathrm{~d}$. Sterile filtered $\mathrm{NaOH}$ and $\mathrm{HCl}$ were used to adjust the $\mathrm{pH}$ of the media (Holt et al., 1994). 


\subsection{Gas production from glucose test of isolates}

Tubes containing $10 \mathrm{~mL}$ MRS and M17 Broth media were prepared. The Durham tubes was placed in reverse position and sterilized in autoclave. $0.1 \mathrm{~mL}$ was taken from the isolates and inoculated with the tubes, and the samples were incubated at $30{ }^{\circ} \mathrm{C}$ for $7 \mathrm{~d}$. (Randazzo et al., 2004).

\subsection{Identification of bacteria with MALDI-TOF MS biotyper}

After identifying the isolates using biochemical methods, pure cultures were also identified using MALDI-TOF MS (Matrix Supported Laser Desorption/Ionization Flight Time Mass Spectrometry, Bruker, Germany) method. The samples were automatically analyzed using a MALDI-TOF mass spectrometry (Bruker, Germany) running Flexcontrol 3.4 software. The mass spectrometry was calibrated using the Bruker's bacterial test standard (Bruker Daltonics) in accordance with the method described by Özcan et al. (2016).

\subsection{Determination of antimicrobial activity of LAB using Kirby-Bauer Disk diffusion method}

100 LAB isolates were inoculated into MRS Broth. The cell concentration of the isolates was adjusted using a densitometry McFarland (Biosan) at a level of 0.5-0.6 McFarland $\left(10^{7} \mathrm{cfu} / \mathrm{ml}\right)$. $20 \mathrm{~mL}$ of sterile MRS Broth supplemented with $1 \%$ isolate were incubated at $30^{\circ} \mathrm{C}$ for $48 \mathrm{~h}$. After incubation, the isolates were centrifuged at $4{ }^{\circ} \mathrm{C}$ and $10,000 \mathrm{rpm}$ for $45 \mathrm{~min}$. Supernatants were sterilized using sterile membrane filters with a pore diameter of $0.22 \mu \mathrm{m}$. (Campos et al., 2008; Uludağ, 2015). Similarly, test microorganisms: L. monocytogenes ATCC 7644, Staph. aureus ATCC 25923, E. coli O157: H7, C. sakazakii ATCC 29544, B. cereus and Salmonella Typhimurium ATCC 140828 were inoculated into TSA and incubated at $37^{\circ} \mathrm{C}$ for $24 \mathrm{~h}$. Cell concentration was set to $10^{7} \mathrm{cfu} / \mathrm{mL}$.

The developing test microorganisms was spread on a trypticase soy agar (TSA) plate. $15 \mu \mathrm{L}$ of supernatants were added onto the discs. The petri dishes were incubated for $24 \mathrm{~h}$ at the temperature appropriate for each indicator pathogen. The following day, the zones of inhibition around the discs in each plate were recorded in $\mathrm{mm}$ (Campos et al., 2008).

\subsection{Partial purification of bacteriocin}

The supernatants obtained previously from lactic acid bacteria contain lactic acid and other organic acids, hydrogen peroxide, bacteriocin and bacteriocin-like substances. Some operations were carried out to observe only the antimicrobial effect of the bacteriocin and bacteriocin-like substances.

First, sterile $\mathrm{NaOH}$ and $\mathrm{HCl}$ were used to adjust the $\mathrm{pH}$ of the supernatant to 7.0 in order to prevent the antimicrobial effect of the organic acids. Afterwards, ammonium sulfate was slowly added to precipitate the proteins into the supernatant. It was mixed with vortex until it was dissolved. The final concentration ratio was found to be $40 \%$. The supernatants were stored overnight at $+4{ }^{\circ} \mathrm{C}$ and then the samples were centrifuged at $+4{ }^{\circ} \mathrm{C}$ and $10,000 \mathrm{rpm}$ for $45 \mathrm{~min}$. After centrifugation, the upper phase was poured. The remaining precipitate was dissolved in $4 \mathrm{~mL}$ of sterile $0.05 \mathrm{M}$ potassium phosphate buffer ( $\mathrm{pH}$ 7.0). The suspended precipitate mixture was used as a partial bacteriocin extract (Uludağ, 2015). Using the same method, antimicrobial tests were performed in three parallel directions on the partially purified bacteriocin extracts. Zone diameters were measured in $\mathrm{mm}$, and means and standard deviations were calculated.

\subsection{Statistical analysis}

All data were expressed as mean \pm standard deviation. Data were analyzed using one-way analysis of variance ANOVA in the Statistical Package for Social Sciences (Version 19.0; SPSS Inc.) at a significance level of $\mathrm{P}<0.05$.

\section{Results and discussion}

\subsection{Identification of lactic acid bacteria}

LAB were biochemically classified according to Bergey's Manual of Systematic Bacteriology published in 1984. Table 2 shows the results of the biochemical tests carried out for the identification of the isolates. Isolate from Bolu Gerede cheese could not be obtained. In this regard, there is no information in this section.

Biochemical identification methods fail to differentiate strains down to the species level. It is, therefore, better to identify strains at the genus level when those methods are used (Dimitonova et al., 2008). Based on the results, homofermentative cocci isolates that grew at $45{ }^{\circ} \mathrm{C}, 6.5 \% \mathrm{NaCl}$ and $\mathrm{pH} 9.6$ were identified as Enterococcus (44\%) (Kim \& Lee, 2013). Cocci-shaped isolates that grew at $10^{\circ} \mathrm{C}$, but not at $45^{\circ} \mathrm{C}, 6.5 \% \mathrm{NaCl}$ and $\mathrm{pH} 9.6$ were identified as Lactococcus (Axelsson, 2004). 46\% of isolates that were rod-shaped and did not produce $\mathrm{CO}_{2}$ from glucose were identified as Lactobacillus while $10 \%$ of those that produced gas from glucose were identified as heterofermentative Leunoconostoc (10\%) (Sezer, 2007). All isolates in the table are Gram (+) and catalase (-). Glucose-free gas formation was not observed in the majority of isolates, indicating that they were homofermentative strains. All identified isolates were stationary.

The combination of molecular and biochemical identification methods allows a more accurate identification (Tabasco et al., 2007). Therefore, these results should be confirmed at the molecular level as well. Table 2 also shows the identification results at the species level by the MALDI-TOF method. LAB colonies isolated from non-commercial cheeses were identified using the recently developed MALDI-TOF MS method, which allows the comparison of resulting profiles with the reference spectrum and rapid classification of isolates. E. durans (6), E. faecalis (18), E. faecium (24), E. italicus (2), Lb. brevis (1), Lb. paracasei (2), Lb. plantarum (1), Lactococcus lactis (3), Leuconostoc lactis (1), Leu. mesenteroides (11), and Streptococcus parauberis (2) were identified using this method. 29 isolates were eliminated because they were identified as yeast and non-lactic acid bacteria.

The results of the MALDI-TOF MS and biochemical identification methods were compared. 55 strains were identified as the same strain at the genus level while 16 strains were identified as different strains at the genus level. Moreover, the identification at the molecular level revealed that although 
Table 2. Biochemical and MALDI-TOF identification results of LAB isolated from cheese samples.

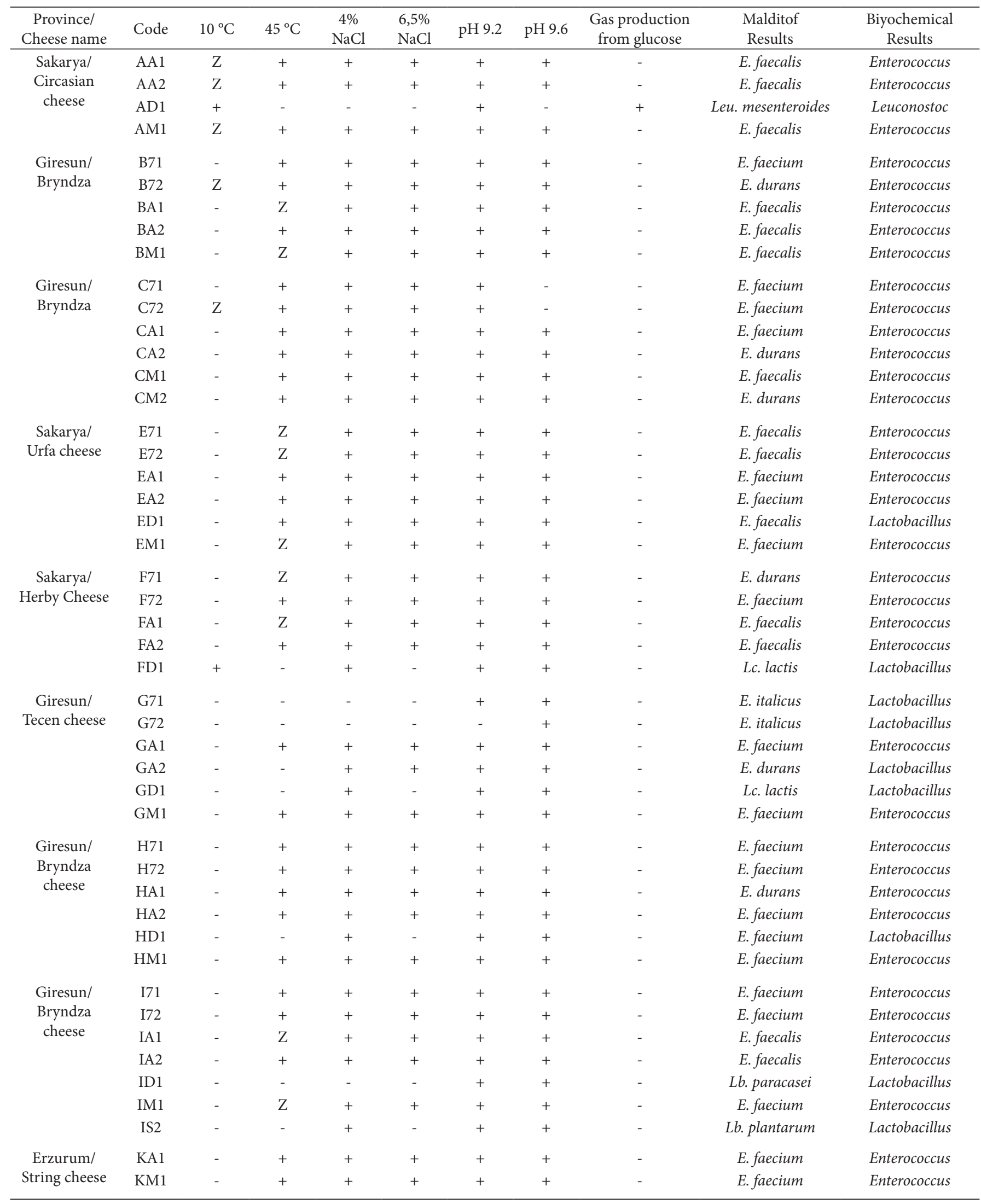

Z: weak reaction, +: positive result, -: negative result. 
Table 2. Continued...

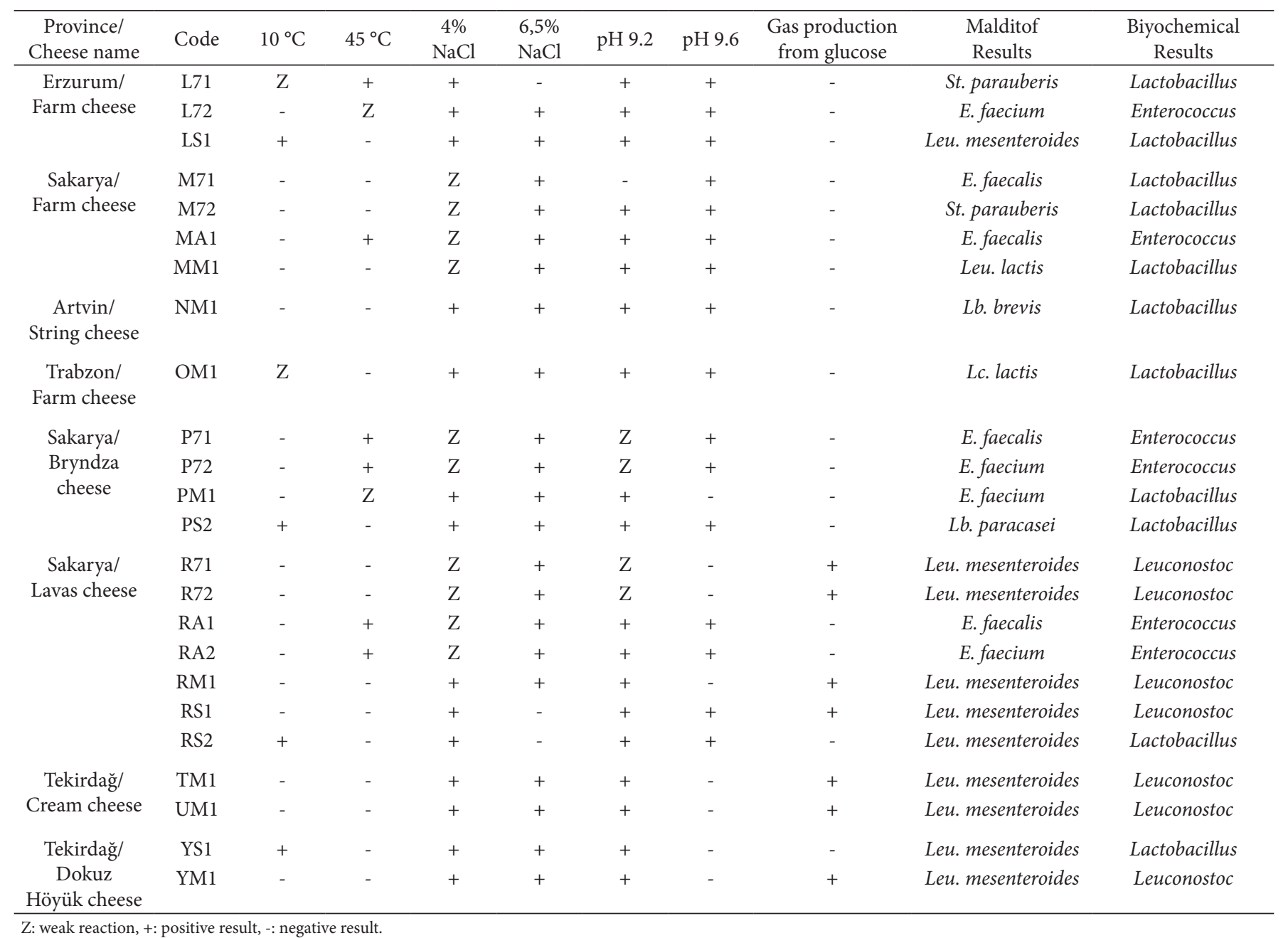

some strains had the same characteristics, they were different bacteria. In parallel with the literature, this result also indicated that the biochemical identification methods are insufficient in differentiating species. Fguiri et al. (2015) identified Lc. lactis, $L b$. pentosus, Lb. plantarum, Lb. brevis and Pediococcus pentosaceus using biochemical methods, however, they identified E. faecium using molecular methods. It has been determined that molecular analysis is the most reliable method for identification.

In general, identification of LAB from cheeses relies on methods based on phenotypic features and/or on physiological and biochemical criteria. However, these complex and time-consuming methods can underestimate the microbiological diversity of a food ecosystem (Ercolini et al., 2001). In contrast, the nucleic acid-based molecular approaches have proven to be powerful tools for the identification of microbial diversity in food samples (Coeuret et al., 2003). The MALDI-TOF MS identification is a rapid, cost-effective, robust and reliable method (Pavlovic et al., 2013). It is, therefore, considered to be an attractive alternative to biochemical and even molecular biological methods (Dec et al., 2014; Vithanage et al., 2014). Dušková et al. (2012) reported that the MALDI-TOF MS method has a higher success rate (93\%) than the polymerase chain reaction (PCR) method (77\%) in identifying Lactobacillus species at the species level. In some cases, the MALDI-TOF MS method allows the identification of bacteria at subspecies level (Carbonnelle et al., 2011). It can be concluded from these results that the MALDI-TOF MS method is affordable, sustainable and robust.

In this study E. faecium and E. faecalis were dominant in all isolates obtained from cheeses according to MALDI-TOF MS method (Figure 1).

Enterococcus bacteria were also detected in 13 cheese varieties. Similarly, studies have reported that enterococci are dominant in many cheeses such as Cebreiro, Kefalotyri, Manchego, Picante in Beira Baixa, Semicotto Caprino, White, Teleme Tomas, Brydza (Öner et al., 2004; Jurkovič et al., 2006; Tuncer, 2009; Yoğurtçu, 2011). Enterococci show very good adaptation to the environment (Tenreiro et al., 2012), which may explain the dominance of cheeses that contain Enterococcus bacteria. E. faecium and E. faecalis are two probiotic species (Erginkaya et al., 2007). Therefore, the probiotic properties of these strains should be further researched and their use as commercial starter cultures should be extensively investigated. 


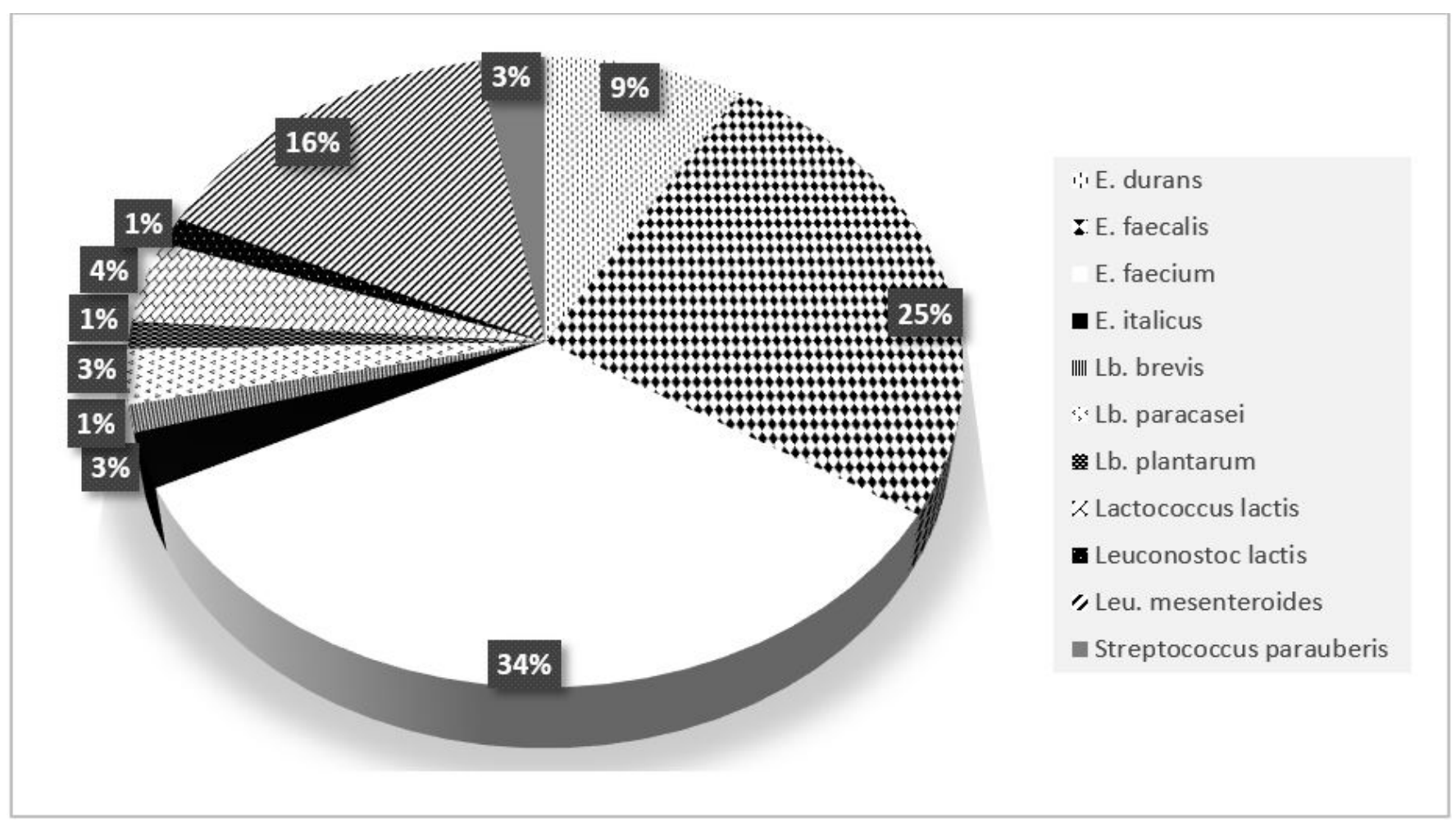

Figure 1. Percent distribution of lactic acid bacteria isolated from all cheeses according to MALDI-TOF MS method.

\subsection{Antimicrobial activities of $L A B$}

The capacity of substances to inhibit microbial growth is referred to as antimicrobial activity. In the study, antimicrobial activity tests were performed on $100 \mathrm{LAB}$ isolated from cheeses. As can be seen in Table 3, antimicrobial activity was observed in 10 isolates. Accordingly, about 10\% of LAB showed antimicrobial activity against 6 pathogens, indicating that most lactic acid bacterial isolates do not exhibit antimicrobial activity. The antimicrobial activity of substances from different isolates of the same strain against pathogens appears to be different from each other, which may be due to different metabolites produced by the sub-species of the isolate.

Many studies have reported that $\mathrm{LAB}$ obtained from cheeses show antimicrobial activity against pathogens such as L. monocytogenes, B. cereus and E. coli (Bilgin 2008; Abanoz 2014; Uludağ 2015). Similarly, $L b$. plantarum isolate (IS2) from Bryndza showed very good antimicrobial activity against $L$. monocytogenes ATCC 7644, E. coli O157:H7, C. sakazakii ATCC 2954 and B. cereus, and the diameter of zones of inhibition ranged from $9 \mathrm{~mm}$ to $15 \mathrm{~mm}$. E. faecium isolate (I71) from Bryndza also showed antimicrobial activity $(15 \mathrm{~mm})$ against C. sakazakii ATCC 29544 . The isolated LAB successfully inhibited these pathogenic strains. Therefore, addition of these isolated LAB to commercial food products can provide effective protection against infections caused by those pathogens. None of the isolates showed antimicrobial activity against Staph. aureus ATCC 25923. Similarly, Samantır (2014) reported that LAB strains isolated from swede did not show any antimicrobial activity against Staph. aureus ATCC 10832.

\subsection{Determination of antimicrobial activity of bacteriocins}

In this study, only two of the partial bacteriocins obtained from isolates (F72, IA2) showed effective antimicrobial activity against pathogens, indicating that the antimicrobial activity of $\mathrm{LAB}$ results from organic acids and low $\mathrm{pH}$ values. Our results agree well with those reported by Sezer (2007) who reported that only 35 of the 601 isolates retained the effect after neutralization.

Several studies have reported that partial bacteriocins obtained from LAB isolates showed antimicrobial effect against S. enteritidis, E. coli, B. cereus, B. subtilis, Salmonella spp., Staph. aureus, Listeria (Sezer, 2007; Uludağ, 2015).

The partial bacteriocin produced by E. faecium obtained from herb cheese formed a zone of inhibition $(9 \mathrm{~mm}$ in diameter) against E. coli O157: $\mathrm{H} 7$ and the partial bacteriocin produced by $E$. faecalis isolated from Bryndza formed a zone of inhibition (11 $\mathrm{mm}$ in diameter) against $S$. Typhimurium ATCC 14028. Only bacteriocins (enterosin) obtained from enterococci protected antimicrobial effects. This may be due to the fact that bacteriocin produced from E. faecium and E. faecalis strains has better physico-chemical properties and biological activities than other bacteriocins (Foulquié Moreno et al., 2003). It has been concluded that bacteriocin produced from $E$. faecium can be used as biological preservatives to extend the shelf life of dairy products. 
Table 3. Antimicrobial effect of lactic acid bacteria against pathogens (Diameter of inhibition zone in $\mathrm{mm}$ ).

\begin{tabular}{|c|c|c|c|c|c|c|}
\hline Lactic acid bacteria & $\begin{array}{c}\text { L. monocytogenes } \\
\text { ATCC } 7644\end{array}$ & $\begin{array}{c}\text { E. coli } \\
\text { O157:H7 }\end{array}$ & $\begin{array}{c}\text { C. sakazakii } \\
\text { ATCC } 29544\end{array}$ & B. cereus & $\begin{array}{l}\text { S. typhimurium } \\
\text { ATCC } 140828\end{array}$ & $\begin{array}{l}\text { Staph. aureus } \\
\text { ATCC } 25923\end{array}$ \\
\hline \multicolumn{7}{|l|}{ Lactic acid bacteria } \\
\hline E.faecalis (AM1) & - & - & $10+1.0 \mathrm{AB}$ & - & - & - \\
\hline E. faecalis (E72) & - & - & $10+1.0 \mathrm{AB}$ & - & - & - \\
\hline E.faecium (EA2) & $14+1.0 \mathrm{AB}$ & - & - & - & - & - \\
\hline E. faecalis (IA1) & $9.5+1.5 \mathrm{~B}$ & - & - & - & - & - \\
\hline E. faecalis (IA2) & - & - & - & - & $12+1.0 \mathrm{AB}$ & - \\
\hline Lb.plantarum (IS2) & $15+1.0 \mathrm{~A}$ & $9+1.0 \mathrm{~B}$ & $11+1.0 \mathrm{AB}$ & $11+1.0 \mathrm{AB}$ & - & - \\
\hline Lc. lactis (OM1) & - & $10.5+2.5 \mathrm{AB}$ & - & - & - & - \\
\hline
\end{tabular}

A, B and AB: The same letters in lines and columns express no difference statistically, different letters express a difference statistically $(\mathrm{P}<0.05)$.

\section{Conclusion}

Consumers' demand for unprocessed food products and reduced use of chemical preservatives in the food industry have led to an increase in the number of studies on the potential use of LAB as biopreservatives against pathogenic bacteria. Traditional cheese products could serve as good and alternative sources of LAB for consumers. In this study, traditional cheeses were found to contain many different antimicrobial LAB and different promising bacteriocins that can be used as food additives. $\mathrm{LAB}$ were found to have components that inhibit pathogen development. Therefore, they can replace the chemical additives in the food industry and contribute to the production of diverse food products. We believe that the use of bacteriocin-producing cultures will improve the quality and safety of food products in an efficient and cost-effective way. Therefore, bacteriocins and/or bacteriocin producing LAB should be added as food preservatives to food products (i.e.; cheese and yoghurt) in order to improve food safety. The results also show that the MALDI-TOF MS is a more accurate, rapid and cost-effective method than biochemical tests for identification of LAB.

\section{Acknowledgements}

The study was financially supported by the Commission of Scientific Research Projects (No: 2017-50-01-006) of Sakarya University. We would like to thank Assoc. Prof. Dr. İpek MUMCUOĞLU for her support in analyse of MALDI-TOF MS.

\section{References}

Abanoz, H. (2014). Enterococcus faecalis Kt11 "in probiyotik potansiyelinin belirlenmesi ve bakteriyosin üretimi üzerine çalışmalar" (Master thesis). Eskişehir, Turkey: Department of Biology, Eskişehir Osmangazi University.

Axelsson, L. (2004). Lactic acid bacteria: classification and physiology (66 p.). New York: Marcel Dekker.

Bilgin, H. (2008). Fermente süt ürününden izole edilen bakteriyosinojenik bir bakterinin antimikrobiyal aktivitesi (Master thesis). Tokat, Turkey: Department of Food Engineering, Gazi Osman Paşa University.

Campos, C. A., Rodriguez, O., Mata, P. C., Prado, M., \& Velazquez, J. B. (2008). Preliminary characterization of bacteriocins from Lactococcus lactis, Enterococcus faecium and Enterococcus mundtii strains isolated from turbot (Psetta Maxima). Food Research International, 7, 432-441.

Carbonnelle, E., Mesquita, C., Bille, E., Day, N., Dauphin, B., Beretti, J., Ferroni, A., Gutmann, L., \& Nassif, X. (2011). MALDI-TOF mass spectrometry tools for bacterial identification in clinical microbiology laboratory. Clinical Biochemistry, 44(1), 104-109. http://dx.doi. org/10.1016/j.clinbiochem.2010.06.017. PMid:20620134.

Coeuret, V., Dubernet, S., Bernardeau, M., Gueguen, M., \& Vernoux, J. (2003). Isolation, characterisation and identification of lactobacilli focusing mainly on cheeses and other dairy products. Le Lait, 83(4), 269-306. http://dx.doi.org/10.1051/lait:2003019.

Dec, M., Urban-Chmiel, R., Gnat, S., Puchalski, A., \& Wernicki, A. (2014). Identification of Lactobacillus strains of goose origin using MALDI-TOF mass spectrometry and 16S-23S rDNA intergenic spacer PCR analysis. Research in Microbiology, 165(3), 190-201. http://dx.doi.org/10.1016/j.resmic.2014.02.003. PMid:24607713.

Dimitonova, S. P., Bakalov, B. V., Aleksandrova-Georgieva, R. N., \& Danova, S. T. (2008). Phenotypic and molecular identification of lactobacilli isolated from vaginal secretions. Journal of Microbiology, Immunology, and Infection, 41(6), 469-477. PMid:19255690.

Dušková, M., Šedo, O., Kšicová, K., Zdráhal, Z., \& Karpíšková, R. (2012). Identification of lactobacilli isolated from food by genotypic methods and MALDI-TOF MS. International Journal of Food Microbiology, 159(2), 107-114. http://dx.doi.org/10.1016/j.ijfoodmicro.2012.07.029. PMid:23072695.

El-Ghaish, S., Khalifa, M., \& Elmahdy, A. (2017). Antimicrobial impact for Lactococcus lactis subsp. lactis A15 and Enterococcus faecium A15 isolated from some traditional Egyptian dairy products on some pathogenic bacteria. Journal of Food Biochemistry, 41(1), e12279. http://dx.doi.org/10.1111/jfbc.12279.

Ercolini, D., Moschetti, G., Blaiotta, G., \& Coppola, S. (2001). The potential of a polyphasic PCR dGGE approach in evaluating microbial diversity of natural whey cultures for water buffalo Mozzarella cheese production: bias of culture-dependent and culture independent analyses. Systematic and Applied Microbiology, 24(4), 610-617. http:// dx.doi.org/10.1078/0723-2020-00076. PMid:11876368.

Erginkaya, Z., Yurdakul, N. E., \& Karakaş, A. (2007). Enterococcus faecium ve Enterococcus faecalis'in starter ve probiyotik kültür özellikleri. Gida, 32(3), 137-142.

Fguiri, I., Ziadi, M., Atigui, M., Arroum, S., \& Khorchani, T. (2015). Biochemical and molecular identification of lactic acid bacteria isolated from camel milk in Tunisia. Emirates Journal of Food and Agriculture, 27(9), 716. http://dx.doi.org/10.9755/ejfa.2015.04.114. 
Foulquié Moreno, M. R., Callewaert, R., Devreese, B., Van Beeumen, J., \& De Vuyst, L. (2003). Isolation and biochemical characterisation of enterocins produced by enterococci from different sources. Journal of Applied Microbiology, 94(2), 214-229. http://dx.doi. org/10.1046/j.1365-2672.2003.01823.x. PMid:12534813.

Halkman, A. K. 2005. Gıda mikrobiyolojisi uygulamaları (pp. 358). Ankara: MERCK, Başak Matbaacılık ve Tanıtım Hizmetleri Ltd. Şti.

Harrigan, W. F., \& McCance, M. E. (1990). Laboratory methods in food and dairy microbiology (8th ed., 452 p.). London: Academic Press.

Holt, J. G., Krieg, N. R., Sneath, P. H. H., Staley, J. T., \& Williams, S. T. (1994). Bergey's manual of determinative bacteriology (9th ed., pp. 787). Baltimore: William \& Wilkins.

Jurkovič, D., Križkova', L., Dušinsky', R., Belicova', A., Sojka, M., Krajčovič, J., \& Ebringer, L. (2006). Identification and characterization of enterococci from bryndza cheese. Letters in Applied Microbiology, 42(6), 553-559. PMid:16706891.

Kačániová, M., Terentjeva, M., Godočíková, L., Puchalski, C., Kunová, S., Kluz, M., Kordiaka, R., \& Haščík, P. (2017). Identification of lactic acid bacteria in milk and milk products with MALDI-TOF mass spectrometry. Scientific Papers: Animal Science \& Biotechnologies, 50(1), 115-120.

Kim, J., \& Lee, C. (2013). Changes in microbial community structure during anaerobic repeated-batch treatment of cheese-processing wastewater. APCBEE Procedia, 5, 520-526. http://dx.doi.org/10.1016/j. apcbee.2013.05.088.

Leroy, F., \& De Vuyst, L. (2004). Lactic acid bacteria as functional starter cultures for the food fermentation industry. Trends in Food Science \& Technology, 15(2), 67-78. http://dx.doi.org/10.1016/j. tifs.2003.09.004.

Macaluso, G., Fiorenza, G., Gaglio, R., Mancuso, I., \& Scatassa, M. L. (2016). In vitro evaluation of bacteriocin-like inhibitory substances produced by lactic acid bacteria isolated during traditional Sicilian cheese making. Italian Journal of Food Safety, 5(1), 5503. http:// dx.doi.org/10.4081/ijfs.2016.5503. PMid:27800430.

Meghoufel, N. L., Homrani, A., Nemmiche, S., Benkrizi, N., Dahou, A. E., \& Zbalah, R. (2017). A brief identification of lactic acid bacteria isolated from Algerian goat's Jben by MALDI-TOF MS. South Asian Journal of Experimental Biology, 7(4), 157-165.

Nacef, M., Chevalier, M., Chollet, S., Drider, D., \& Flahaut, C. (2017). MALDI-TOF mass spectrometry for the identification of lactic acid bacteria isolated from a French cheese: the Maroilles. International Journal of Food Microbiology, 247, 2-8. http://dx.doi.org/10.1016/j. ijfoodmicro.2016.07.005. PMid:27423415.

Öner, Z., Sağdiç, O., \& Şimşek, B. (2004). Lactic acid bacteria profiles and tyramine and tryptamine contents of Turkish tulum cheeses. European Food Research and Technology, 219(5), 455-459. http:// dx.doi.org/10.1007/s00217-004-0962-x.

Özcan, N., Ezin, Ö., Akpolat, N., Bozdağ, H., Mete, M., \& Gül, K. (2016). Klinik örneklerde saptanan Candida türlerinin MALDI-TOF MS ile tiplendirilmesi. Dicle Medikal Journal, 43(3), 390-394.
Pavlovic, M., Huber, I., Konrad, R., \& Busch, U. (2013). Application of MALDI-TOF MS for the identification of food borne bacteria. The Open Microbiology Journal, 7(1), 135-141. http://dx.doi.org/10.217 4/1874285801307010135. PMid:24358065.

Pidcock, K., Heard, G. M., \& Henriksson, A. (2002). Application of nontraditional meat starter cultures in production of Hungarian salami. International Journal of Food Microbiology, 76(1-2), 75-81. http://dx.doi.org/10.1016/S0168-1605(02)00002-8. PMid:12038580.

Randazzo, C. L., Restuccia, C., Romano, A. D., \& Caggia, C. (2004). Lactobacillus casei, dominant species in naturally fermented Sicilian green olives. International Journal of Food Microbiology, 90(1), 9-14. http://dx.doi.org/10.1016/S0168-1605(03)00159-4. PMid:14672826.

Samantır, N. (2014). Şalgam suyundan izole edilen laktik asit bakterilerinin 16S rRNA ile tanımlanması ve bazı gelişme parametrelerinin belirlenmesi (PhD thesis). Department of Food Engineering, Ankara University, Ankara, Turkey.

Sezer, Ç. (2007). Gıdalardan izole edilen laktik asit bakterilerinin bakteriyosin üretme yeteneklerinin araştırılması ( $\mathrm{PhD}$ thesis). Department of Food Engineering, Ankara University, Ankara, Turkey.

Tabasco, R., Paarup, T., Janer, C., Peláez, C., \& Requena, T. (2007). Selective enumeration and identification of mixed cultures of Streptococcus thermophilus, Lactobacillus delbrueckii subsp. bulgaricus, L. acidophilus, L. paracasei subsp. paracasei and Bifidobacterium lactis in fermented milk. International Dairy Journal, 7(9), 1107-1114. http://dx.doi.org/10.1016/j.idairyj.2007.01.010.

Temiz, A. (2000). Genel Mikrobiyoloji Uygulama Teknikleri (3rd ed., 291 p.). Ankara: Hatipoğlu.

Tenreiro, R., Barreto-Crespo, M. T., \& Semedo-Lemsaddek, T. (2012). Enterococcus and safety. New York: Nova Science Publishers, Inc.

Tulini, F. L., Hymery, N., Haertlé, T., Le Blay, G., \& De Martinis, E. C. (2016). Screening for antimicrobial and proteolytic activities of lactic acid bacteria isolated from cow, buffalo and goat milk and cheeses marketed in the southeast region of Brazil. The Journal of Dairy Research, 83(01), 115-124. http://dx.doi.org/10.1017/ S0022029915000606. PMid:26608755.

Tuncer, Y. (2009). Some technological properties of phenotypically identified enterococci strains isolated from Turkish tulum cheese. African Journal of Biotechnology, 8(24), 7008-7016.

Uludağ, H. 2015. Klinik ve gıda kaynaklı enterokoklar tarafindan üretilen bakteriyosinlerin bazı patojen bakteriler üzerine antimikrobiyal etkilerinin karşılaştırılması (Master thesis). Department of Food Engineering, Çukurova University, Ankara, Turkey.

Vithanage, N. R., Yeager, T. R., Jadhav, S. R., Palombo, E. A., \& Datta, N. (2014). Comparison of identification systems for psychrotrophic bacteria isolated from raw bovine milk. International Journal of Food Microbiology, 189, 26-38. http://dx.doi.org/10.1016/j. ijfoodmicro.2014.07.023. PMid:25113043.

Yoğurtçu, N. N. (2011). Tulum peynirinden enterokok suşlarının izolasyonu ve antibiyotik duyarliliklarmm belirlenmesi (Master thesis). Department of Food Engineering, Süleyman Demirel University, Isparta, Turkey. 